\title{
THE ROLE OF SURFACE ANTIGENS IN THE PROTECTIVE POTENCY OF BORDETELLA PERTUSSIS SUSPEN- SIONS AS MEASURED BY THE INTRACEREBRAL CHALLENGE TECHNIQUE IN MICE
}

\author{
L. B. Holt and Vera Spasojevíc * \\ Department of Applied Immunology, Wright-Fleming Institute, \\ St Mary's Hospital Medical School, London
}

WE have found that the strain of Bordetella pertussis (18/323) most commonly used for challenge in the intracerebral protection technique in mice (WHO Technical Report Series no. 61) grows as well on blood agar as on BordetGengou medium.

When viable counts are made by the method of Miles and Misra (Miles, Misra and Irwin, 1938) in parallel on Bordet-Gengou and on blood agar different counts may be obtained. Strain $18 / 323$ gave the same count on both media, but a further 12 strains gave variable results. A few gave similar counts on both, but most gave either fewer colonies or smaller ones on blood agar.

Suspensions obtained from blood agar however differed qualitatively from similar suspensions from Bordet-Gengou medium: when they were tested with phase-I serum and with typing sera containing agglutinins to Andersen's (1953) factors 1,2 or 3 , they showed reduced or no agglutination. To measure the agglutinability of suspensions, and for purposes of comparison, the semiquantitative method of Preston (1965) was used. Although this method is not truly quantitative, it gives good correlation with the amount of surface antigens in the suspension. When strains were passed back from blood agar to BordetGengou medium the antigens that were apparently lost reappeared. The phenomenon clearly resembles "modulation" described by Lacey in 1960. Organisms in Lacey's $C$ mode are also deficient in serotype agglutinogens. It seemed of interest therefore to study organisms in this mode for their protective ability, and to compare them with organisms that had lost their surface antigens owing to cultivation on blood agar. In the past it has been assumed that $C$-mode organisms would be non-protective because they had lost the surface antigens.

\section{METHODS}

Media. Bordet-Gengou plates were prepared in the usual way with 20 per cent. v/v sheep blood, unless otherwise specified.

Blood agar plates contained a base of the following composition: peptone (Oxoid L 37) $10 \mathrm{~g}$; Tryptone (Oxoid L 42) $2 \mathrm{~g}$; $\mathrm{NaCl} 5 \mathrm{~g}$; Lab. Lemco (Oxoid) $10 \mathrm{~g}$; distilled water to 1 litre; agar (Difco) $15 \mathrm{~g}$. The mixture was adjusted to $p \mathrm{H} 7.6$ before the agar was added,

* Present address: Institute for Sera and Vaccines, Torkal, Belgrade, Yugoslavia. Received 11 Jan. 1968; accepted 3 Mar. 1968.

J. MED. MICROBIOL.-VOL. 1 (1968) 
and the whole was autoclaved for $20 \mathrm{~min}$. at $115.5^{\circ} \mathrm{C}$. Plates were poured with $25 \mathrm{ml}$ of the base and were overlayered with $12 \mathrm{ml}$ of the same base containing 6 per cent. $\mathrm{v} / \mathrm{v}$ of defibrinated sheep blood.

Cohen and Wheeler's (1946) medium was used as modified by Holt (1962) and is referred to in the text as "routine vaccine medium ". When the medium was used for the production of $C$-mode organisms the $\mathrm{NaCl}$ was omitted and in its place 1.1 per cent. $\mathrm{MgSO}_{4} .7 \mathrm{H}_{2} \mathrm{O}(\mathrm{w} / \mathrm{v})$ was added.

Incubation. All the cultures were incubated at $34-35^{\circ} \mathrm{C}$ aerobically. Bordet-Gengou plates were incubated for 3 days, blood agar plates 4-8 days and the routine vaccine medium for 3 days. The challenge organism was grown on Bordet-Gengou medium for $18 \mathrm{hr}$. Some of the cultures were incubated in 5 per cent. $\mathrm{CO}_{2}$ in air because this was found to increase the agglutinability of many strains.

Sera. Typing sera were prepared and kindly provided by Dr N. W. Preston. These will be referred to as "monospecific" sera as they are used to identify specific surface antigens (Preston, 1963). Those used were phase-I serum (obtained from the Central Public Health Laboratory, Colindale) and "monospecific sera" 1,2 and 3.

Analysis of the agglutinogens. The suspensions were killed by heating at $56^{\circ} \mathrm{C}$ for $30 \mathrm{~min}$. and preserved with 1 in 10,000 Thiomersal. The technique employed was that described by Preston (1963).

Reading of results. This consists of slide agglutination, in which ++++ is allotted to gross agglutination occurring within $15 \mathrm{~s},+++$ to rapid agglutination that is complete within $3 \mathrm{~min}$., + + to agglutination within $3 \mathrm{~min}$. and complete within $5 \mathrm{~min}$., + to agglutination that is incomplete within $5 \mathrm{~min} ., \pm$ to very slow agglutination, inapparent within $5 \mathrm{~min}$. and incomplete within $10 \mathrm{~min}$. No agglutination is denoted by - . This notation will be referred to as the "agglutination rating".

Mouse protection tests were carried out in the manner recommended by the World Health Organization (W.H.O. Technical Rep. series 61) in which female white mice of strain I.C.I. are used. The suspensions tested as vaccines were first standardised by opacity against the ground-glass standard of the National Institute of Health, Bethesda, to conform to 10 standard units of Bordetella pertussis. This opacity corresponds approximately to $10_{10}$ organisms per $\mathrm{ml}$. Of these suspensions dilutions were made as stated and doses of $0.5 \mathrm{ml}$ were given intraperitoneally to the mice 14 days before the intracerebral challenge with $5 \times 10^{4}$ organisms (c. 10 per cent. viable) of strain $18 / 323$ Bordetella pertussis in $0.025 \mathrm{ml}$. This dose corresponds to $150 \mathrm{LD} 50$. The results were expressed as a fraction in which the survivors 14 days after the challenge are the numerator and the total number alive 3 days after the challenge is the denominator. The ratio is referred to in the tables at $\mathrm{S} / \mathrm{T}$.

\section{EXPERIMENTAL}

Several strains were tested in the $X$ mode and were found to give good protection in mice and were agglutinated by one or more of the " monotypic sera". The same strains were grown in a high $\mathrm{Mg}^{++}$medium according to the method of Lacey to obtain $C$-mode organisms. These organisms had lost their agglutinability and afforded little or no protection. Since the organisms grown on blood agar resembled the $C$-mode organisms in their loss of agglutinability, it was decided to test them for their protective potency to see whether they differed from $C$-mode organisms.

As a preliminary experiment strain B138 of Bordetella pertussis was tested in $X$ mode and $C$ mode for mouse protection (table I). It was found, as expected, that $C$-mode organisms afforded little protection. It was then decided to explore whether the loss of protection was associated with the loss of agglutinability. 
Three strains of Bord.pertussis were grown on Bordet-Gengou and on blood agar media. The six resulting suspensions were tested for agglutinability and mouse protection along with controls (table II). Two of the three strains lost the antigenic factors associated with types when grown on blood agar, but they still retained all their protective ability. To avoid carry-over of any protective antigen all the blood agar cultures were tested in their third subculture on this medium. The results (table III) indicate that the agglutinogens responsible for phase I and types 1, 2 and 3 reactions are not related to the protective antigens in mice. It is also clear that $C$-mode organisms are not identical with those obtained from blood agar: the former are non-agglutinable by type sera and non-protective, the latter are non-agglutinable but fully protective.

TABLE I

Agglutinability with various antisera, and mouse protective ability against strain 18/323, of strains of Bordetella pertussis grown in different ways

\begin{tabular}{|c|c|c|c|c|c|c|c|}
\hline \multirow{2}{*}{ Strain } & \multirow{2}{*}{ Medium } & \multicolumn{4}{|c|}{$\begin{array}{l}\text { Agglutination rating against } \\
\text { antiserum }\end{array}$} & \multirow{2}{*}{$\begin{array}{l}\text { Dose of } \\
\text { vaccine } \\
\text { (million } \\
\text { organisms) }\end{array}$} & \multirow{2}{*}{$\mathrm{S} / \mathrm{T}$} \\
\hline & & Ph. I & $\mathrm{T}_{1}$ & $\mathrm{~T}_{2}$ & $\mathrm{~T}_{3}$ & & \\
\hline Vaccine $\mathrm{B} 138$ & $\begin{array}{c}\text { Routine vaccine } \\
\text { medium } \rightarrow \\
X \text {-mode organisms }\end{array}$ & +++ & +++ & +++ & +++ & 1000 & $18 / 18$ \\
\hline Vaccine B138 & $\underset{\text { routine medium } \rightarrow}{\text { High } \mathrm{Mg}^{++}}$ & - & - & - & - & 1000 & $2 / 18$ \\
\hline Challenge $18 / 323^{*}$ & Bordet-Gengou & $+t$ & $+t+$ & ++ & - & 0 & $0 / 15$ \\
\hline
\end{tabular}

* Challenge throughout 150 LD50 strain 18/323 intracerebrally.

Since both the Bordet-Gengou and the blood agar plates contained sheep blood it seemed of interest to study the roles of the blood and of the serum. The Bordet-Gengou medium contained 20 per cent. $\mathrm{v} / \mathrm{v}$ of defibrinated sheep blood, which corresponds to about 10 per cent. of serum throughout the plate. The blood agar plate contained 6 per cent. of blood in the top layer only, which corresponds to about 1 per cent. serum throughout the plate. Several strains of Bord.pertussis were grown on nutrient agar $(30 \mathrm{ml}$ per plate) to which $0.6 \mathrm{ml}$ of packed sheep red cells and varying amounts of sheep serum were added. The results with two strains are shown in table IV. For testing, a single human serum was used which gave high titres of agglutination by conventional techniques with $X$-mode strains of Bord.pertussis. The table clearly shows the requirement for a certain concentration of sheep serum in the plate for the development of agglutinability. The amount required for full agglutinability is more than twice that which was used in the two-layer blood agar plates in the previous experiments. 
Some workers use horse blood and others sheep blood for the cultivation of Bord. pertussis. In further experiments these were compared. Blood agar plates were poured with 4, 6 and 10 per cent. of horse or sheep blood in the upper

TABLE II

Agglutinability, and mouse-protective values against strain $18 / 323$, of vaccines prepared from three strains of Bordetella pertussis grown on different media

\begin{tabular}{|c|c|c|c|c|c|c|c|}
\hline \multirow{2}{*}{ Strain } & \multirow{2}{*}{ Medium } & \multicolumn{4}{|c|}{$\begin{array}{l}\text { Agglutination rating against } \\
\text { antiserum }\end{array}$} & \multirow{2}{*}{$\begin{array}{l}\text { Dose of } \\
\text { vaccine } \\
\text { (million } \\
\text { organisms) }\end{array}$} & \multirow{2}{*}{$\mathrm{S} / \mathrm{T}$} \\
\hline & & Ph. I & $\mathrm{T}_{1}$ & $T_{2}$ & $\mathbf{T}_{3}$ & & \\
\hline Vaccine B3067 . & $\begin{array}{c}\left\{\begin{array}{c}\text { Bordet-Gengou } \\
, "\end{array}\right. \\
\left\{\begin{array}{c}\text { blood agar } \\
", \\
",\end{array}\right.\end{array}$ & $\begin{array}{c}+++ \\
-\end{array}$ & $\begin{array}{c}+++ \\
\pm\end{array}$ & $\begin{array}{c}+++ \\
-\end{array}$ & +++ & $\begin{array}{r}2000 \\
400 \\
80 \\
2000 \\
400 \\
80\end{array}$ & $\begin{array}{r}11 / 15 \\
9 / 15 \\
4 / 15 \\
12 / 15 \\
9 / 14 \\
2 / 15\end{array}$ \\
\hline Vaccine B1741 & $\begin{array}{c}\left\{\begin{array}{c}\text { Bordet-Gengou } \\
, "\end{array}\right. \\
\left\{\begin{array}{c}\text { blood agar } \\
, "\end{array}\right.\end{array}$ & - & + & ++ & ++ & $\begin{array}{r}2000 \\
400 \\
80 \\
2000 \\
400 \\
80\end{array}$ & $\begin{array}{r}12 / 15 \\
12 / 15 \\
2 / 15 \\
\\
11 / 15 \\
4 / 15 \\
1 / 15\end{array}$ \\
\hline Vaccine B1772 & $\begin{array}{c}\left\{\begin{array}{c}\text { Bordet-Gengou } \\
" ”\end{array}\right. \\
\left\{\begin{array}{c}\text { blood agar } \\
, "\end{array}\right.\end{array}$ & $\begin{array}{l}+++ \\
+++\end{array}$ & $\begin{array}{l}+++ \\
+++\end{array}$ & $\begin{array}{c}++ \\
+\end{array}$ & $\begin{array}{c}++ \\
\pm\end{array}$ & $\begin{array}{r}2000 \\
400 \\
80 \\
2000 \\
400 \\
80\end{array}$ & $\begin{array}{r}12 / 15 \\
9 / 14 \\
9 / 15 \\
\\
12 / 15 \\
5 / 15 \\
1 / 14\end{array}$ \\
\hline $\begin{array}{l}\text { Vaccine DS2/16 } \\
\text { (Laboratory } \\
\text { standard } \\
\text { vaccine) }\end{array}$ & $\begin{array}{l}\text { Routine vaccine } \\
\text { medium }\end{array}$ & ++ & ++ & +++ & ++ & $\begin{array}{r}2000 \\
400 \\
80\end{array}$ & $\begin{array}{r}12 / 15 \\
5 / 15 \\
0 / 15\end{array}$ \\
\hline Challenge $18 / 323$ * & Bordet-Gengou & +++ & +++ & ++ & \pm & 0 & $0 / 15$ \\
\hline
\end{tabular}

* Challenge throughout 150 LD50 strain 18/323 intracerebrally.

layers. Similarly Bordet-Gengou plates were prepared with the two kinds of blood. Four strains of Bord. pertussis were grown on all of these media and the suspensions were tested for agglutinability and protective effect. The 32 suspensions gave widely different agglutinability depending on the amount of serum in the plates, but the mouse protection was uniformly high throughout. 
TABLE III

Agglutinability, and mouse-protective values against strain 18/323, of vaccines made from four strains of Bordetella pertussis grown on two different media: all subcultured three times in succession on each medium

\begin{tabular}{|c|c|c|c|c|c|c|c|}
\hline \multirow{2}{*}{ Strain } & \multirow{2}{*}{ Medium } & \multicolumn{4}{|c|}{$\begin{array}{l}\text { Agglutination rating against } \\
\text { antiserum }\end{array}$} & \multirow{2}{*}{$\begin{array}{l}\text { Dose of } \\
\text { vaccine } \\
\text { (million } \\
\text { organisms) }\end{array}$} & \multirow{2}{*}{$\mathrm{S} / \mathrm{T}$} \\
\hline & & Ph. I & $\mathrm{T}_{1}$ & $T_{2}$ & $\mathrm{~T}_{3}$ & & \\
\hline Vaccine B3067 . & $\begin{array}{l}\left\{\begin{array}{c}\text { Bordet-Gengou } \\
, "\end{array}\right. \\
\left\{\begin{array}{c}\text { blood agar } \\
,\end{array}\right.\end{array}$ & $\begin{array}{l}++ \\
-\end{array}$ & $\begin{array}{l}++ \\
-\end{array}$ & $\begin{array}{c}++ \\
-\end{array}$ & $\begin{array}{l}++ \\
-\end{array}$ & $\begin{array}{r}2000 \\
200 \\
2000 \\
200\end{array}$ & $\begin{array}{r}15 / 16 \\
8 / 14 \\
15 / 16 \\
9 / 16\end{array}$ \\
\hline Vaccine B149 & $\begin{array}{l}\left\{\begin{array}{c}\text { Bordet-Gengou } \\
, "\end{array}\right. \\
\left\{\begin{array}{c}\text { blood agar } \\
,\end{array}\right.\end{array}$ & $\begin{array}{l}+++ \\
++\end{array}$ & $\begin{array}{l}++ \\
+\end{array}$ & $\begin{array}{l}+++ \\
++\end{array}$ & $\begin{array}{l}- \\
-\end{array}$ & $\begin{array}{r}2000 \\
200 \\
2000 \\
200\end{array}$ & $\begin{array}{r}15 / 16 \\
6 / 16 \\
15 / 16 \\
5 / 16\end{array}$ \\
\hline Vaccine B1772 & $\begin{array}{l}\left\{\begin{array}{c}\text { Bordet-Gengou } \\
,\end{array}\right. \\
\left\{\begin{array}{c}\text { blood agar } \\
,\end{array}\right.\end{array}$ & $\begin{array}{c}++ \\
-\end{array}$ & $\begin{array}{l}++ \\
-\end{array}$ & $\begin{array}{c}++ \\
-\end{array}$ & $\begin{array}{c}++ \\
-\end{array}$ & $\begin{array}{r}2000 \\
200 \\
2000 \\
200\end{array}$ & $\begin{array}{l}15 / 15 \\
16 / 16 \\
14 / 14 \\
14 / 15\end{array}$ \\
\hline Vaccine B1741 & $\begin{array}{l}\left\{\begin{array}{c}\text { Bordet-Gengou } \\
, "\end{array}\right. \\
\left\{\begin{array}{c}\text { blood agar } \\
, "\end{array}\right.\end{array}$ & $\begin{array}{l}+ \\
\pm\end{array}$ & $\begin{array}{l}++ \\
-\end{array}$ & $\begin{array}{l}++ \\
\pm\end{array}$ & $\begin{array}{c}++ \\
+\end{array}$ & $\begin{array}{r}2000 \\
200 \\
2000 \\
200\end{array}$ & $\begin{array}{r}11 / 16 \\
5 / 16 \\
16 / 16 \\
1 / 15\end{array}$ \\
\hline Challenge $18 / 323 *$ & Bordet-Gengou & +++ & +++ & ++ & \pm & 0 & $0 / 16$ \\
\hline
\end{tabular}

* Challenge throughout 150 LD50 strain 18/323 intracerebrally.

TABLE IV

The influence of serum concentration on the production of agglutinogens by two strains of Bordetella pertussis

\begin{tabular}{|c|c|c|}
\hline \multirow{2}{*}{$\begin{array}{l}\text { Per cent. serum } \\
(\mathrm{v} / \mathrm{v}) \text { in medium }\end{array}$} & \multicolumn{2}{|c|}{$\begin{array}{c}\text { Agglutination titre of } X \text {-mode antiserum } \\
\text { against cultures of }\end{array}$} \\
\hline & strain B1772 & strain B3067 \\
\hline $\begin{array}{l}0 \\
0 \cdot 5 \\
1 \cdot 0 \\
2 \cdot 0 \\
5 \cdot 0 \\
10 \cdot 0\end{array}$ & $\begin{array}{r}<2 \\
<2 \\
10 \\
250 \\
400 \\
400\end{array}$ & $\begin{array}{r}<2 \\
32 \\
30 \\
250 \\
250 \\
400\end{array}$ \\
\hline
\end{tabular}


The problem was next investigated from the point of view of the ability of the microbes to stimulate rabbits to produce agglutinins. One strain (Glaxo 353Z) was chosen on account of its known mouse pathogenicity and its lack of agglutinability. Another strain (B124) was chosen because of its high agglutination rating with all the type sera and its lack of mouse pathogenicity. Both strains were grown on Bordet-Gengou medium and vaccines were prepared with Freund's complete adjuvant. Rabbits were vaccinated with 4 subcutaneous injections, each containing 8000 million organisms, simultaneously. Four weeks later the sera were tested for agglutinating activity against a highly agglutinable strain (B2288). Passive mouse protection tests were also carried out. The results are shown in table $\mathrm{V}$. The strain poor in agglutinogens induced virtually no production of agglutinins, whereas the other strain produced high titre serum in the rabbit. Nevertheless both strains gave the same measure of mouse protection by passive immunisation.

\section{TABLE V}

Comparison of a highly agglutinable and a non-agglutinable strain of Bordetella pertussis for their power to stimulate agglutinating and mouse-protecting antibodies

\begin{tabular}{|c|c|c|c|c|c|c|}
\hline \multicolumn{5}{|c|}{ Vaccine } & \multicolumn{2}{|c|}{ Antiserum against vaccine strain } \\
\hline \multirow{2}{*}{ Strain } & \multicolumn{4}{|c|}{ Agglutination rating against antiserum } & \multirow{2}{*}{$\begin{array}{c}\text { Homologous } \\
\text { agglutination } \\
\text { titre }\end{array}$} & \multirow{2}{*}{$\begin{array}{c}\text { Mouse PD50 * against } \\
150 \text { LD50 of strain } \\
18 / 323\end{array}$} \\
\hline & Ph. I & $\mathrm{T}_{1}$ & $\mathrm{~T}_{2}$ & $\mathbf{T}_{3}$ & & \\
\hline Gl. $353 Z$ & \pm & - & - & - & 2 & $0 \cdot 15 \mathrm{ml}$ \\
\hline B124 & ++++ & +++ & $+t+$ & +++ & 1000 & $0.15 \mathrm{ml}$ \\
\hline
\end{tabular}

* 1 PD50 is the volume of serum required for each mouse to protect 50 per cent. of those challenged.

Finally, the role of factor 7 in mouse protection could be ruled out. All four of our typing sera contained antibodies to factor 7 as shown by the fact that they strongly agglutinated Bord. parapertussis and Bord. bronchiseptica. These two organisms were ineffective as vaccines against Bord. pertussis when tested in mice.

\section{Discussion}

Though it is generally accepted that mouse protection is a good indication of the protective value against whooping cough of a strain used for the manufacture of a vaccine, little is known about the true nature of the antigen or antigens involved. Preston (1965) is of the opinion that the agglutinogen factors used in typing play a part. His argument is mainly based on the fact that in recent years increasing numbers of Bordetella pertussis strains have been isolated in Britain possessing type factor 3. He assumes that this is due to the use of 
commercial vaccines that are deficient in this antigen; such vaccines would be less protective against type 3 strains.

The experimental work suggests that this is not the correct interpretation. Though the prevalence of type 3 strains is not in doubt, there are other possible explanations: i.e., the possession of type-3 agglutinogen together with some other antigens in the currently prevalent virulent strains. This would be difficult to tackle at the moment, but the role of the type factors can be elucidated. All the evidence presented shows that the possession of the type factors employed in agglutination is independent of the protective ability of the strain when used as a vaccine. It must be concluded therefore that in mouse protection-as well as in the prophylaxis of whooping cough-another antigen or antigens play the essential role. This conclusion is in good agreement with the findings of Horton and Standfast (1953), who used a stored vaccine that had liberated all its agglutinogens into the supernatant fluid, leaving the microbes themselves inagglutinable. When the supernatant was used as antigen it failed to confer protection on mice, while the inagglutinable residual bacteria protected. Similar conclusions were drawn by Eldering, Holwerda and Baker (1967) from studies on passive immunity on mice.

It is concluded that the presence of thermolabile agglutinogens types 1,2 and 3 and of the stable type 7 , studied in this work, provides no information on the suitability of a strain for use as a vaccine.

\section{SUMMARY}

The growth of different strains of Bordetella pertussis on a variety of media frequently leads to the loss of the surface antigens known as Andersen's factors 1,2 and 3. When such suspensions were used as vaccines they were found to be as protective to mice challenged with Bord. pertussis strain $18 / 323$ by the intracerebral route as the parent strains grown in the conventional way and possessing these antigens. Conversely, vaccines prepared from strains of Bord. bronchiseptica and Bord. parapertussis showed poor protection against Bord. pertussis, although they shared type-7 antigen with it.

When antisera were prepared in rabbits by means of suspensions rich in type 1, 2 and 3 antigens and compared with sera prepared against suspensions lacking these factors no clear correlation was found in the protective effect. Some sera rich in agglutinins and others virtually devoid of them proved equally protective in the passive immunity test in mice.

It is therefore suggested that Andersen's agglutinogens 1,2, 3 and 7 play no part in the protective effect of vaccines. Some other antigen or antigens must be associated with the protection of mice and presumably also of children.

\section{REFERENCES}

Andersen, Else K. ～. . . . . . . . 1953. Acta path. microbiol. scand., 33, 202.

Cohen, Sophia M., and Wheeler, Mary 1946. Amer.J. Publ. Hlth, 36, 371. W.

Eldering, Grace, Holwerda, J., and 1967. J. Bact., 93, 1758.

BAKER, JULIA 


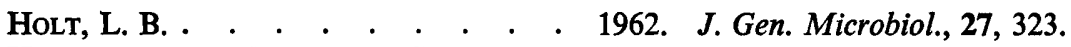

Horton, Jean M., and Standfast, 1953. Proc. VI Congr. Int. Microbiol., Rome, A. F. B. $2,335$.

LACEY, B. W. - . . . . . . . . . 1960. J. Hyg., Camb., 58, 57.

Miles, A. A., Misra, S. S., AND IRWIN, 1938. Ibid., 38, 732. J. $O$.

PReston, N. W. . . . . . . . . 1963. Br. Med. J., 2, 724.

" . . . . . . . . 1965. Ibid., 2, 11. 